\title{
Dermatoses among returned Canadian travellers and immigrants: surveillance report based on CanTravNet data, 2009-2012
}

\author{
Michael S. Stevens BScPT MD, Jennifer Geduld MSc, Michael Libman MDCM, Brian J. Ward MDCM, \\ Anne E. McCarthy MD, Jean Vincelette MD, Wayne Ghesquiere MD, Jan Hajek MD, Susan Kuhn MD, \\ David O. Freedman MD, Kevin C. Kain MD, Andrea K. Boggild MSc MD
}

\section{Abstract}

Background: There is a lack of multicentre analyses of the spectrum of dermatologic illnesses acquired by Canadian travellers and immigrants. Our objective for this study was to provide a comprehensive, Canada-specific surveillance summary of travel-related dermatologic conditions in a cohort of returned Canadian travellers and immigrants.

\begin{abstract}
Methods: Data for Canadian travellers and immigrants with a primary dermatologic diagnosis presenting to CanTravNet sites between September 2009 and September 2012 were extracted and analyzed. Data were collected using the GeoSentinel data platform. This network comprises 56 specialized travel and tropical medicine clinics, including 6 Canadian sites (Vancouver, Calgary, Toronto, Ottawa and Montréal), that contribute anonymous, de-linked, clinician- and questionnaire-based travel surveillance data on all ill travellers examined to a centralized Structure Query Language database. Results were analyzed according to reason for most recent ravel: immigration (including refugee); tourism; business; missionary/volunteer/research and aid work; visiting friends and relatives; and other, which included students, military personnel and medical tourists.
\end{abstract}

Results: During the study period, 6639 patients presented to CanTravNet sites across Canada and 1076 (16.2\%) received a travelrelated primary dermatologic diagnosis. Arthropod bites $(n=162,21.5 \%)$, rash $(n=141,18.7 \%)$, cutaneous larva migrans $(n=98$, $13.0 \%)$, and skin and soft tissue infection ( $n=92,12.2 \%)$ were the most common dermatologic diagnoses or diagnostic bundles issued to returning Canadian tourists ( $n=754,70.1 \%$ of total sample). Patients travelling for the purpose of immigration $(n=63$, $5.9 \%)$ were significantly more likely to require inpatient management of their dermatologic diagnoses $(p<0.001)$ than those travelling for other purposes.

Interpretation: This analysis of surveillance data details the spectrum of travel-related dermatological conditions among returning Canadian travellers in this cohort, and provides an epidemiologic framework for Canadian physicians encountering these patients.

anadians are increasingly engaging in international travel. Top destinations chosen by travelling Canadians include tropical and developing-world countries such as Mexico, Cuba, Dominican Republic and Jamaica. ${ }^{1}$ At the same time, new Canadian immigrants and their families are travelling to their countries of birth to visit friends and relatives, and business travellers, researchers, volunteers and missionaries are seeking out opportunities in an increasingly wide variety of foreign destinations. The trend toward increased global exploration by Canadian travellers is supported by data from the World Tourism Organization and Statistics Canada: in 2012, Canadians spent US\$35.2 billion on international tourism, up from US\$33.0 billion in 2011 and US\$29.6 billion in $2010 .^{2}$ In fact, Canada is now the sixth largest spender on international travel worldwide. ${ }^{3}$
Travel to the developing world and tropics places travellers at risk of environmental and infectious exposures. Skin disorders or dermatoses are among the leading causes of health problems in travellers and are among the most common reasons for which returned travellers seek medical care. ${ }^{4-6}$ Singlecentre studies in France ${ }^{7}$ and the United States ${ }^{4}$ and international studies performed by the GeoSentinel Surveillance

Competing interests: See end of the article.

This article has been peer reviewed.

Correspondence to: Andrea Boggild, andrea.boggild@utoronto.ca CMAJ Open 2015. DOI:10.9778/cmajo.20140082 
Network ${ }^{5,6}$ showed that dermatoses are the third most common medical problem in returned international travellers.

Although single-centre studies from other countries and multinational studies of travel-acquired dermatoses have been conducted, there is a lack of a comprehensive multicentre synthesis of travel-acquired dermatoses among Canadians who have returned from international travel. Our understanding of the range and frequency of dermatoses in Canadian travellers is based primarily on existing synthesized knowledge of travelacquired dermatoses in other populations.

Our objective was to synthesize Canada-specific surveillance data on travel-acquired dermatoses with the goal of providing an accurate epidemiologic framework to minimize misdiagnosis or delayed diagnosis. This analysis also aims to better inform clinical decision-making by frontline Canadian practitioners who are the first points of contact for returned Canadian travellers who seek medical care. In addition, we have outlined an appropriate diagnostic approach for the tropical dermatologic diseases seen in this cohort of returned Canadian travellers.

\section{Methods}

\section{Setting and sources of data}

Six Canadian sites from 4 provinces, which also belong to the global GeoSentinel Surveillance Network, have grouped together to form the core sites of CanTravNet. The 6 Canadian sites are large, referral-based outpatient clinics that primarily serve the Greater Vancouver, Victoria, Calgary, Toronto, Ottawa and Montréal areas, which together account for $47 \%$ of the Canadian population (or a catchment of about 15.5 million people). The Calgary site was a new CanTravNet site in 2012 and did not contribute cases during the surveillance period. The sites are staffed by specialists in travel and tropical medicine, and are typically secondary or tertiary points of care for patients, although immediate referral from the emergency departments attached to the respective parent hospitals is common. All of the centres provide post-travel services, which are billed to the respective provincial health plans. Further details regarding CanTravNet can be found at www.cantravnet.ca, and additional details regarding the CanTravNet data source and definitions are as described. ${ }^{8}$

Data were collected using the GeoSentinel data platform. This network comprises 56 specialized travel and tropical medicine clinics on 6 continents, which contribute anonymous, de-linked clinician- and questionnaire-based travel surveillance data on all ill travellers examined to a centralized Structured Query Language database ${ }^{6}$ (for additional details see www.geosentinel.org).

\section{Definitions}

The following definitions were used in this study.

Reason for most recent travel: 6 possible designations for the purpose of travel were used: immigration (including refugee); tourism; business; missionary/volunteer/research or aid work; visiting friends and relatives; and other, which includes students, military personnel and medical tourists. Those travelling for immigration include patients whose diagnosis is related to their emigration travel or long-term residence in their home country rather than a particular isolated international trip. ${ }^{9}$ Visiting friends and relatives travel is defined as an immigrant who is ethnically and racially distinct from the majority population in their current country of residence and who returns to his or her homeland to visit friends and relatives, or children of parents born elsewhere (i.e., secondgeneration immigrants) who return to their parent's homeland to visit friends and relatives. Additional definitions for purpose of travel are as described. ${ }^{8}$

Countries of exposure and travel were assigned to 1 of 14 regional classifications as described. ${ }^{8}$

\section{Inclusion criteria}

Demographic, clinical and travel-related data for Canadian citizens and new immigrants to Canada who were encountered after completion of their international travel or residence abroad and seen at a CanTravNet site between September 2009 and September 2012 were extracted and analyzed. Patients diagnosed with a dermatologic illness were included in the analysis.

\section{Statistical analysis}

Extracted data were managed in a Microsoft Access database, and analyzed using standard parametric and nonparametric techniques. Comparisons between categorical variables were made using Yates' correction $\left(\chi^{2}\right)$ analysis, and continuous variables were analyzed for significant differences using the Mann-Whitney test for non-normally distributed parameters. Differences between groups of continuous variables were compared using the Kruskal-Wallis test. All tests were 2 -sided. All statistical computations were performed using SigmaStat 2.03 software (SPSS Inc.). Level of significance was set at $p<0.05$.

\section{Resullts}

\section{Patient characteristics}

During the surveillance period, 6639 travellers presented to CanTravNet Surveillance Network sites across Canada. Of these, $1076(16.2 \%)$ received a primary dermatologic diagnosis. Those patients who received a primary dermatologic diagnosis were seen at the following CanTravNet sites: MontréalMcGill $(n=619,57.5 \%)$, Toronto $(n=277,25.7 \%)$, Montréal-Centre Hospitalier de l'Université de Montréal $(n=87,8.1 \%)$, Ottawa $(n=52,4.8 \%)$ and Vancouver $(n=41$, $3.8 \%)$. Demographic variables, including purpose of travel, for the cohort of 1076 returned travellers with a primary dermatologic diagnosis are summarized in Table 1.

The primary reason for travel among study participants was tourism; the most frequently visited regions by were the Caribbean $(n=242,22.5 \%)$, Central America $(n=197,18.3 \%)$, SubSaharan Africa $(n=138,12.8 \%)$, Southeast Asia $(n=114$, $10.6 \%)$ and Southcentral Asia $(n=84,7.8 \%)$. Figure 1 depicts regional exposure. Participants who travelled to visit friends and relatives, and those who travelled for missionary/volunteer/research or aid work, had longer trip durations than par- 
ticipants who travelled for the purpose of tourism $(p<0.001)$ (Table 1). Participants who travelled to visit friends and relatives were the least likely to have obtained pretravel consultation $(p<0.02)$ (Table 1).

\section{Diagnoses}

Table 2 summarizes the top dermatologic diagnoses for all returned Canadian travellers who presented to a CanTravNet site during the surveillance period. The 10 most frequent der-

\begin{tabular}{|c|c|c|c|c|c|c|c|}
\hline \multirow[b]{2}{*}{ Characteristic } & \multirow[b]{2}{*}{$\begin{array}{c}\text { All, no. (\%) } \\
n=1076\end{array}$} & \multicolumn{6}{|c|}{ Purpose of travel, no. (\%)* } \\
\hline & & $\begin{array}{l}\text { Tourism } \\
n=754\end{array}$ & $\begin{array}{c}\text { Immigration } \\
n=63\end{array}$ & $\begin{array}{c}\text { VFR } \\
n=78\end{array}$ & $\begin{array}{c}\text { Missionary } \\
\text { volunteer/ } \\
\text { researcher/aid } \\
n=84\end{array}$ & $\begin{array}{c}\text { Business } \\
n=69\end{array}$ & $\begin{array}{l}\text { Other† } \\
n=28\end{array}$ \\
\hline \multicolumn{8}{|l|}{ Sex } \\
\hline Male & $448(41.6)$ & $300(39.8)$ & $36(57.1)$ & $32(41.0)$ & 28 (33.3) & $34(49.3)$ & $18(64.3)$ \\
\hline Female & $628(58.4)$ & $454(60.2)$ & $27(42.9)$ & $46(59.0)$ & $56(66.7)$ & $35(50.7)$ & $10(35.7)$ \\
\hline Age, yr; median (IQR) & $39.7(26-52)$ & $39(27-53)$ & $36(22.5-59.8)$ & $39(28-54)$ & $29(22.3-51)$ & $39(32.8-50)$ & $25(22-40)$ \\
\hline \multicolumn{8}{|l|}{ Patient type } \\
\hline Inpatient & $27(2.5)$ & $13(1.7)$ & $6(9.5)$ & $2(2.6)$ & $2(2.4)$ & $2(2.9)$ & $2(7.1)$ \\
\hline Outpatient & $1049(97.5)$ & $741(98.3)$ & $57(90.5)$ & $76(97.4)$ & $82(97.6)$ & $67(97.1)$ & $26(92.9)$ \\
\hline $\begin{array}{l}\text { Travel duration, d; median } \\
\text { (IQR) }\end{array}$ & $15.5(7-31)$ & $14(7-27)$ & NA & $33(16.5-79)$ & $28(14.8-61.3)$ & $21(8.8-35)$ & $24(9.3-111)$ \\
\hline \multicolumn{8}{|l|}{ Pretravel encounter } \\
\hline Yes & $364(33.8)$ & $238(31.6)$ & NA & $18(23.1)$ & $60(71.4)$ & $32(46.4)$ & $16(57.1)$ \\
\hline No & $387(36.0)$ & $310(41.1)$ & NA & $39(50.0)$ & $9(10.7)$ & $23(33.3)$ & $6(21.4)$ \\
\hline Unknown & $262(24.3)$ & $206(27.3)$ & NA & $21(26.9)$ & 15 (17.9) & $14(20.3)$ & $6(21.4)$ \\
\hline \multicolumn{8}{|l|}{ CanTravNet site } \\
\hline Montréal & $619(57.5)$ & 447 (59.3) & $26(41.3)$ & $38(48.7)$ & $60(71.4)$ & $34(49.3)$ & $14(50.0)$ \\
\hline Toronto & $277(25.7)$ & $192(25.5)$ & $16(25.4)$ & $31(39.7)$ & $11(13.1)$ & $25(36.2)$ & $2(7.1)$ \\
\hline Montréal-CHUM & $87(8.1)$ & $72(9.5)$ & $0(0)$ & $2(2.6)$ & $10(11.9)$ & $3(4.3)$ & $0(0)$ \\
\hline Ottawa & $52(4.8)$ & $22(2.9)$ & $12(19.0)$ & $4(5.1)$ & $3(3.6)$ & $3(4.3)$ & $8(28.6)$ \\
\hline Vancouver & $41(3.8)$ & $21(2.8)$ & $9(14.3)$ & $3(3.8)$ & $0(0)$ & $4(5.8)$ & $4(14.3)$ \\
\hline \multicolumn{8}{|l|}{ Region of exposure } \\
\hline Caribbean & $242(22.5)$ & 206 (27.3) & $2(3.2)$ & $6(7.7)$ & $16(19.0)$ & $10(14.5)$ & $2(7.1)$ \\
\hline Central America & $197(18.3)$ & $180(23.9)$ & $2(3.2)$ & $2(2.6)$ & $4(4.8)$ & $4(5.8)$ & $5(17.9)$ \\
\hline Sub-Saharan Africa & $138(12.8)$ & $51(6.8)$ & $20(31.7)$ & $15(19.2)$ & $32(38.1)$ & $14(20.3)$ & $6(21.4)$ \\
\hline Southeast Asia & $114(10.6)$ & $85(11.3)$ & $9(14.3)$ & $6(7.7)$ & $7(8.3)$ & $6(8.7)$ & $1(3.6)$ \\
\hline Southcentral Asia & $84(7.8)$ & $35(4.6)$ & $12(19.0)$ & $20(25.6)$ & $5(6.0)$ & $6(8.7)$ & $6(21.4)$ \\
\hline South America & $71(6.6)$ & $41(5.4)$ & $2(3.2)$ & $9(11.5)$ & $14(16.7)$ & $3(4.3)$ & $2(7.1)$ \\
\hline North America & $64(5.9)$ & $57(7.6)$ & $0(0)$ & $0(0)$ & $0(0)$ & $6(8.7)$ & $1(3.6)$ \\
\hline Western Europe & $24(2.2)$ & $19(2.5)$ & $0(0)$ & $2(2.6)$ & $0(0)$ & $3(4.3)$ & $0(0)$ \\
\hline Northeast Asia & $19(1.8)$ & $7(0.9)$ & $7(11.1)$ & $3(3.8)$ & $0(0)$ & $2(2.9)$ & $0(0)$ \\
\hline Eastern Europe & $13(1.2)$ & $2(0.3)$ & $11.6)$ & $7(9.0)$ & $0(0)$ & $2(2.9)$ & $1(3.6)$ \\
\hline North Africa & $12(1.1)$ & $3(0.4)$ & $1(1.6)$ & $5(6.4)$ & $1(1.2)$ & $2(2.9)$ & $0(0)$ \\
\hline Middle East & $12(1.1)$ & $3(0.4)$ & $5(7.9)$ & $1(1.3)$ & $1(1.2)$ & $1(1.4)$ & $1(3.6)$ \\
\hline Oceania & $4(0.4)$ & $4(0.5)$ & $0(0)$ & $0(0)$ & $0(0)$ & $0(0)$ & $0(0)$ \\
\hline Australia/New Zealand & $3(0.3)$ & $1(0.1)$ & $0(0)$ & $1(1.3)$ & $0(0)$ & $1(1.4)$ & $0(0)$ \\
\hline Unknown & $79(7.3)$ & $60(8.0)$ & $2(3.2)$ & $1(1.3)$ & $4(4.8)$ & $9(13.0)$ & $2(7.1)$ \\
\hline
\end{tabular}


matologic diagnoses for the cohort were rash, arthropod bites, skin and soft tissue infections, cutaneous larva migrans, pruritus (unknown origin), animal bites, fungal infections, cutaneous leishmaniasis, marine envenomation and infestations. Significant differences in trip duration were also seen between participants with different primary dermatologic diagnoses $(p<0.001)$ (Table 2). Specifically, the diagnosis of cutaneous leishmaniasis was associated with a longer trip duration (median $=35 \mathrm{~d}$ ) than marine envenomation (median trip duration $=8 \mathrm{~d}$ ) or cutaneous larva migrans (median trip duration = $10 \mathrm{~d})(p<0.001)$. Table 3 summarizes the top 3 dermatologic diagnoses by travel region.

Table 4 summarizes the top dermatologic diagnoses for the cohort of returned Canadian travellers based on their reason for travel. Returned tourists accounted for most of the cases of cutaneous larva migrans (93.3\%) and myiasis (72.2\%) observed in the cohort (Tables 3 and 4). The top 3 source countries for cutaneous larva migrans, Jamaica, Mexico and Barbados (Table 2), accounted for $53.3 \%$ of all cases. The top 3 source countries for myiasis, Costa Rica, Belize and Uganda (Table 2), accounted for $67.6 \%$ of all cases.

The most frequent diagnosis among those travelling for the purpose of immigration $(n=63)$ was leprosy $(n=15,23.84 \%)$ (Table 4). The top 3 source countries for leprosy, Sri Lanka, Philippines and India (Table 2), accounted for $73.3 \%$ of all cases. Although those travelling for the purpose of immigration comprised only $5.9 \%(n=63)$ of the travellers seen during the surveillance period, they were significantly more likely than those who travelled for other purposes to require inpatient management of their dermatologic diagnoses $(9.5 \%$ v. $2.1 \%$ of nonimmigrant travellers managed as inpatients, $p<0.001)$.
Participants who travelled to visit friends and relatives were more likely to receive a diagnosis of cutaneous leishmaniasis $(p<0.001)$ (Table 4). Cutaneous leishmaniasis was also over-represented among participants who immigrated $(p<0.01)$ (Table 4).

\section{Interpretation}

Dermatologic conditions are a leading health problem in returned Canadian travellers. About 16\% of the 6639 patients presenting to CanTravNet sites during the study period had a primary dermatologic diagnosis, making skin lesions the second most common symptom after gastrointestinal symptoms. Of the top 13 dermatologic presentations in returned Canadian travellers in this cohort, only 4 are classical tropical infections or infestations: cutaneous larva migrans, cutaneous leishmaniasis, myiasis and leprosy. Most of the primary cutaneous diagnoses reported in this study are cosmopolitan dermatoses that could have been acquired outside the context of travel. The prevalence of tropical dermatoses in the cohort was most dependent on the destination visited and the reason for travel. Returned tourists accounted for most cases of cutaneous larva migrans and myiasis. In contrast, all cases of leprosy were seen in the subgroup of participants who immigrated, supporting the long-held impression that leprosy is rarely found among Canadian travellers, but is seen in those born and raised in endemic countries. Participants who immigrated were significantly more likely to be given a dermatologic diagnosis requiring inpatient management, which likely reflects the over-representation of diagnoses, such as leprosy and tuberculosis, in this group of travellers. These results underscore the

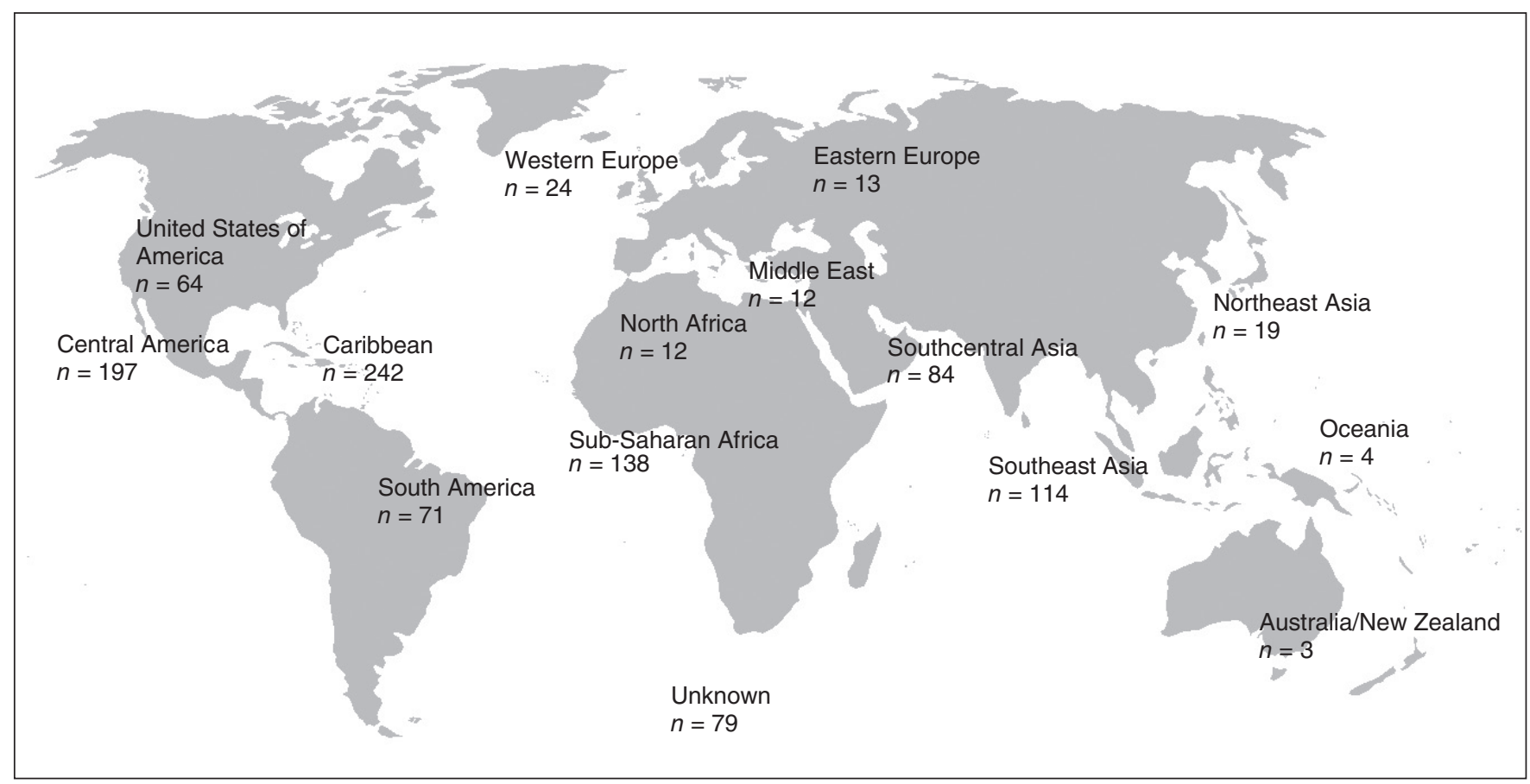

Figure 1: Regional exposure for the cohort of returned travellers $(n=1076)$ with a primary travel-related dermatologic diagnosis presenting to a CanTravNet site in Canada. 


\begin{tabular}{|c|c|c|c|c|}
\hline Diagnosis & $\begin{array}{l}\text { No. } \\
\text { derm } \\
\text { diag }\end{array}$ & $\begin{array}{l}\text { \% of all } \\
\text { atologic } \\
\text { loses) }\end{array}$ & Top 3 source countries for diagnosis & $\begin{array}{l}\text { Trip duration, d; } \\
\text { median (IQR) }\end{array}$ \\
\hline 1. Rash & 212 & \multirow[t]{9}{*}{$(19.7)$} & \multirow{9}{*}{$\begin{array}{l}\text { Mexico; Cuba; India, Costa Rica, Dominican } \\
\text { Republic (tied) }\end{array}$} & \multirow[t]{9}{*}{$15(7-32.75)$} \\
\hline Unknown etiology, nonfebrile & 77 & & & \\
\hline Atopic dermatitis & 40 & & & \\
\hline Contact dermatitis & 33 & & & \\
\hline Urticaria/angioedema & 28 & & & \\
\hline Photosensitivity & 19 & & & \\
\hline Drug related & 11 & & & \\
\hline Sea bather's eruption & 3 & & & \\
\hline Heat induced & 1 & & & \\
\hline 2. Arthropod bites & 207 & \multirow[t]{5}{*}{$(19.2)$} & \multirow[t]{5}{*}{ United States, Cuba, Mexico } & \multirow[t]{5}{*}{$14(7-23)$} \\
\hline Insect bites; including stings & 142 & & & \\
\hline Tick bites & 38 & & & \\
\hline Insect bites, superinfected & 24 & & & \\
\hline Spider bites & 3 & & & \\
\hline 3. Skin and soft tissue infection & 156 & \multirow[t]{5}{*}{$(14.5)$} & \multirow[t]{5}{*}{ Cuba, India, United States } & \multirow[t]{5}{*}{$29(10-63)$} \\
\hline Superficial & 94 & & & \\
\hline Skin and soft tissue & 27 & & & \\
\hline Skin abscess & 17 & & & \\
\hline Secondary infection of existing skin lesion & 18 & & & \\
\hline 4. Cutaneous larva migrans & 105 & $(9.8)$ & Jamaica, Mexico, Barbados & $10(7-18.75)$ \\
\hline 5. Pruritus, unknown origin & 65 & $(6.0)$ & Dominican Republic, Cuba, Ghana & $14(7-29)$ \\
\hline 6. Animal bites & 56 & \multirow[t]{5}{*}{$(5.2)$} & \multirow[t]{5}{*}{ Thailand; Indonesia; Chile, Mexico, India (tied) } & \multirow[t]{5}{*}{$22(14.25-36)$} \\
\hline Monkey & 25 & & & \\
\hline Dog & 18 & & & \\
\hline Other $^{*}$ & 10 & & & \\
\hline Cat & 3 & & & \\
\hline Required rabies PEP & 47 & & & \\
\hline 7. Fungal infection (superficial/cutaneous mycosis) & 46 & $(4.3)$ & Cuba, Mexico, India & $22(8-61)$ \\
\hline 8. Cutaneous leishmaniasis & 36 & (3.3) & $\begin{array}{l}\text { Costa Rica, Syrian Arab Republic, } \\
\text { Afghanistan }\end{array}$ & $35(23.5-56.75)$ \\
\hline 9. Marine envenomation $\dagger$ & 32 & $(3.0)$ & United States, Mexico, Cuba & $8(7-14)$ \\
\hline 10. Infestations & 26 & \multirow[t]{4}{*}{ (2.4) } & \multirow[t]{4}{*}{ India, Panama, Dominican Republic } & \multirow[t]{4}{*}{$23(14.25-64.5)$} \\
\hline Scabies & 22 & & & \\
\hline Lice & 3 & & & \\
\hline Mites & 1 & & & \\
\hline 11. Myiasis & 18 & $(1.7)$ & Costa Rica, Belize, Uganda & $16.5(9-24)$ \\
\hline 12. Leprosy & 15 & $(1.4)$ & Sri Lanka, Philippines, India & NA $\ddagger$ \\
\hline 13. Psoriasis & 10 & $(0.9)$ & $\begin{array}{l}\text { Vietnam; Thailand, Russia, Philippines, } \\
\text { Jamaica, Cambodia (tied) }\end{array}$ & $18(4.5-29)$ \\
\hline $\begin{array}{l}\text { NOTE: PEP = postexposure prophylaxis. } \\
{ }^{*} \text { Includes bites from a bat, }{ }^{6} \text { tiger, }{ }^{1} \text { stingray }{ }^{1} \text { and leech. }{ }^{1} \\
\text { tIncludes envenomations from jellyfish and other cnidarians, sea } \\
\text { because this is otherwise classified. } \\
\ddagger \text { Not applicable. The reason for travel in leprosy cases is immigrati }\end{array}$ & ne, s & ray an & omous fish. This does not include envenomations from sec & ather's eruption, \\
\hline
\end{tabular}


need for a full risk assessment of Canadians with a history of immigration that extends far beyond the details of their most recent travel.

Arthropod bites were one of the top 3 dermatologic diagnoses for all nonimmigrant travellers in the study, accounting for $19.2 \%$ of dermatologic diagnoses. The high prevalence of arthropod bites and arthropod-borne disease across all travel categories underscores the importance of providing pretravel preventative education for all Canadian travellers.

The prevalence of dermatologic diagnoses in our study is consistent with multinational or single-centre studies in other countries, ${ }^{5,6,10}$ which found dermatologic conditions to be the third most common health problem in returned international travellers. A large, networkwide GeoSentinel analysis reported similar findings: primary dermatologic conditions were diagnosed in $17 \%$ of the 17353 international travellers who returned to one of 30 GeoSentinel sites on 6 continents. ${ }^{6}$ A decline in the prevalence of classical tropical dermatologic diseases has been reported: ${ }^{11}$ from as high as $53 \%$ in a prospective study of the diagnoses in 269 returned French travellers presenting to a tropical disease unit in Paris in the early $1990 \mathrm{~s}^{12}$ to as low as $24 \%$ in a multiregional GeoSentinel study published in 2008. ${ }^{5}$ Confirmed tropical dermatoses in our cohort were even less common, accounting for only $16.4 \%$ of all primary dermatologic diagnoses; however, specific causes for many of the rashes were unavailable.

The results of this study are consistent with previous multinational or single-centre studies from other countries, which

\begin{tabular}{|lcl|}
\hline \multicolumn{2}{|c|}{ Table 3: Top 3 dermatologic diagnoses, by region } \\
\hline $\begin{array}{l}\text { Region of } \\
\text { exposure }\end{array}$ & $\begin{array}{c}\text { Travellers } \\
\text { returning with } \\
\text { dermatoses, no. }\end{array}$ & \multicolumn{1}{c|}{ Top 3 diagnoses } \\
\hline Caribbean & 242 & $\begin{array}{l}\text { Cutaneous larva migrans, } \\
\text { arthropod bites, rash* }\end{array}$ \\
\hline Central America & 197 & $\begin{array}{l}\text { Arthropod bites, rash, } \\
\text { cutaneous larva migrans }\end{array}$ \\
\hline $\begin{array}{l}\text { Sub-Saharan } \\
\text { Africa }\end{array}$ & 138 & $\begin{array}{l}\text { Rash, }{ }^{*} \text { skin and soft tissue } \\
\text { infections, arthropod bites }\end{array}$ \\
\hline Southeast Asia & 114 & $\begin{array}{l}\text { Rabies (PEP), animal bites, } \\
\text { skin and soft tissue infection }\end{array}$ \\
\hline $\begin{array}{l}\text { Southcentral } \\
\text { Asia }\end{array}$ & 84 & $\begin{array}{l}\text { Arthropod bites, skin and soft } \\
\text { tissue infections, rash (atopic } \\
\text { dermatitis) }\end{array}$ \\
\hline South America & 71 & $\begin{array}{l}\text { Skin and soft tissue } \\
\text { infections, rash, }{ }^{*} \text { arthropod } \\
\text { bites }\end{array}$ \\
\hline North America & 64 & $\begin{array}{l}\text { Arthropod bites, skin and soft } \\
\text { tissue infections, rash } \\
\text { (contact dermatitis) }\end{array}$ \\
\hline Western Europe & 24 & $\begin{array}{l}\text { Arthropod bites, rash } \\
\text { (angioedema), pruritus } \\
\text { (unknown origin) }\end{array}$ \\
\hline $\begin{array}{l}\text { Note: PEP = postexposure prophylaxis. } \\
\text { Top specific rash was of unknown cause. }\end{array}$ & & \\
\hline & & \\
\hline
\end{tabular}

also reported arthropod bites as one of the top 3 dermatologic diagnoses in returned travellers. ${ }^{4,5}$ The use of $N, N$-diethyl-mtoluamide or picaridin-based insect repellents and protective clothing, as well as other personal protective measures including bed nets, was recommended by the Public Health Agency of Canada's Committee to Advise on Tropical Medicine and Travel. ${ }^{13}$

\section{Limitations}

This analysis has several limitations. First, the data analyzed represent a sample of returned Canadian travellers and new immigrants who are ill, capturing only those travellers who presented to CanTravNet sites during the 3-year surveillance period. Therefore, the overall incidence of primary dermatoses in all returned Canadian international travellers and immigrants, or the risk of acquiring a dermatologic condition in a specific destination cannot be estimated from these data. ${ }^{6,14}$ Consequently, our results may not extend to all returned Canadian travellers with skin disorders. Second, patients with self-limited or less severe skin lesions, or those with very short or prolonged incubation periods, may have presented to other health care providers (e.g., their primary physican or a dermatologist). Third, immigrants and first-generation travellers visiting friends and relatives may have been less likely than tourist travellers to seek care for symptoms that may be perceived as "benign" (e.g., arthropod bites, rashes). Fourth, we only included patients seen after travel; therefore, our analysis will not have captured those who sought care for a rash or skin lesion during travel. Fifth, given that nearly two-thirds $(65.6 \%)$ of the patients in this study were seen at 2 sites in Montréal, interprovince variation in travel patterns has the potential to introduce bias. Finally, there was a larger proportion of women and girls in the cohort, accounting for $58.4 \%$ of returned travellers and immigrants. The over-representation of females may represent care-seeking bias, greater vigilance regarding skin diseases, in particular, compared with men, or underlying and undescribed biologic susceptibilities.

\section{Conclusion}

Our analysis provides an epidemiologic framework that can help guide clinical decision-making by front-line Canadian practitioners who are the first point of contact for most returned travellers who seek medical care. Accurate knowledge of the spectrum of dermatologic conditions acquired by Canadians who are travelling for a variety of purposes and to ever-expanding regions of the globe can also help to maximize the preventative impact of physicians and public health agencies offering pretravel resources and advice. We have outlined our approach to categorizing dermatologic presentations in the returned traveller, and an overview of appropriate diagnostic testing for the most common travel-acquired tropical dermatoses is presented to assist front-line physicians who see returned travellers (Appendix 1, Table S1, available at www. cmajopen.ca/content/3/1/E119/suppl/CD1). In addition, we provide practical, action-oriented pretravel advice for the prevention of common skin conditions seen in returned travellers (Appendix 1, Table S2). 
Table 4: Top 5 dermatologic diagnoses, by reason for travel $(n=1076)$

\begin{tabular}{|c|c|c|c|c|c|c|}
\hline & $\begin{array}{l}\text { Tourism } \\
(n=754)\end{array}$ & $\begin{array}{l}\text { Immigration } \\
\quad(n=63)\end{array}$ & $\begin{array}{c}\text { VFR } \\
(n=78)\end{array}$ & $\begin{array}{l}\text { Missionary/volunteer/ } \\
\text { researcher/aid } \\
(n=84)\end{array}$ & $\begin{array}{l}\text { Business } \\
(n=69)\end{array}$ & $\begin{array}{l}\text { Other* }^{*} \\
(n=28)\end{array}$ \\
\hline 1. & $\begin{array}{l}\text { Arthropod bite } \\
(n=167,22.1 \%) \\
\text { - Insect bite, including } \\
\quad \text { stings }(n=117) \\
\text { - Tick bite }(n=29) \\
\text { - Insect bite, } \\
\text { superinfected }(n=18) \\
\text { - Spider bite }(n=3)\end{array}$ & $\begin{array}{l}\text { Leprosy } \\
(n=15,23.8 \%)\end{array}$ & $\begin{array}{l}\text { Arthropod bite } \\
(n=15,19.2 \%) \\
\text { - Insect bite, including } \\
\text { stings }(n=6) \\
\text { - Tick bite }(n=5) \\
\text { - Insect bite, } \\
\quad \text { superinfected }(n=4)\end{array}$ & $\begin{array}{l}\text { Rash } \\
(n=23,27.4 \%) \\
\text { - Unknown cause, } \\
\text { nonfebrile }(n=8) \\
\text { - Atopic dermatitis } \\
(n=4) \\
\text { - Urticaria/angioedema } \\
(n=4) \\
\text { - Contact dermatitis } \\
(n=3) \\
\text { - Photosensitivity }(n=3) \\
\text { - Drug related }(n=1)\end{array}$ & $\begin{array}{l}\text { Rash } \\
(n=17,24.6 \%) \\
\text { - Unknown cause, } \\
\text { nonfebrile }(n=6) \\
\text { - Atopic dermatitis } \\
(n=6) \\
\text { - Contact dermatitis } \\
(n=2) \\
\text { - Drug related }(n=2) \\
\text { - Urticaria/angioedema } \\
(n=1)\end{array}$ & $\begin{array}{l}\text { Skin and soft tissue } \\
\text { infection } \\
(n=13,46.4 \%) \\
\text { - Superficial }(n=9) \\
\text { - Skin and soft tissue } \\
(n=2) \\
\text { - Skin abscess }(n=1) \\
\text { - Secondary infection of } \\
\text { existing lesion }(n=1)\end{array}$ \\
\hline 2. & $\begin{array}{l}\text { Rash } \\
(n=141,18.7 \%) \\
\text { - Unknown cause, } \\
\text { nonfebrile }(n=50) \\
\text { - Contact dermatitis } \\
(n=28) \\
\text { - Atopic dermatitis } \\
(n=24) \\
\text { - Urticaria/angioedema } \\
(n=18) \\
\text { - Photosensitivity } \\
(n=16) \\
\text { - Seabather's eruption } \\
\text { (n=3) } \\
\text { - Drug related }(n=1) \\
\text { - Heat induced }(n=1)\end{array}$ & $\begin{array}{l}\text { Rash } \\
(n=13,20.6 \%) \\
\text { - Drug related }(n=6) \\
\text { Unknown etiology, } \\
\text { nonfebrile }(n=4) \\
\text { - Atopic dermatitis } \\
(n=2) \\
\text { - Urticaria/angioedema } \\
(n=1)\end{array}$ & $\begin{array}{l}\text { Rash } \\
(n=15,19.2 \%) \\
\text { - Unknown cause, } \\
\text { nonfebrile }(n=9) \\
\text { - Atopic dermatitis } \\
(n=2) \\
\text { - Urticaria/angioedema } \\
(n=3) \\
\text { - Drug related }(n=1)\end{array}$ & $\begin{array}{l}\text { Skin and soft tissue } \\
\text { infection } \\
(n=18,21.4 \%) \\
\text { - Superficial }(n=12) \\
\text { - Skin and soft tissue } \\
(n=2) \\
\text { - Skin abscess }(n=3) \\
\text { - Secondary bacterial } \\
\text { infection of existing } \\
\text { lesion }(n=1)\end{array}$ & $\begin{array}{l}\text { Skin and soft tissue } \\
\text { infection } \\
(n=14,20.3 \%) \\
\text { - Superficial }(n=5) \\
\text { - Skin and soft tissue } \\
(n=2) \\
\text { - Skin abscess }(n=3) \\
\text { - Secondary bacterial } \\
\text { infection of existing } \\
\text { lesion }(n=4)\end{array}$ & $\begin{array}{l}\text { Arthropod bite } \\
(n=3,10.7 \%) \\
\text { - Insect bite, including } \\
\text { stings }(n=2) \\
\text { - Tick bite }(n=1)\end{array}$ \\
\hline 3. & $\begin{array}{l}\text { Cutaneous larva migrans } \\
(n=98,13.0 \%)\end{array}$ & $\begin{array}{l}\text { Pruritus, unknown origin } \\
(n=7,11.1 \%)\end{array}$ & $\begin{array}{l}\text { Skin and soft tissue } \\
\text { infection } \\
(n=13,16.7 \%) \\
\text { - Superficial }(n=9) \\
\text { - Skin and soft tissue } \\
(n=3) \\
\text { - Secondary infection of } \\
\text { existing lesion }(n=1)\end{array}$ & $\begin{array}{l}\text { Arthropod bite } \\
(n=12,14.3 \%) \\
\text { - Insect bite, including } \\
\text { stings }(n=10) \\
\text { - Tick bite }(n=1) \\
\text { - Insect bite, } \\
\text { superinfected }(n=1)\end{array}$ & $\begin{array}{l}\text { Arthropod bite } \\
(n=9,13.0 \%) \\
\text { - Insect bite, including } \\
\text { stings }(n=6) \\
\text { - Tick bite }(n=2) \\
\text { - Insect bite, } \\
\text { superinfected }(n=1)\end{array}$ & $\begin{array}{l}\text { Leishmaniasis, } \\
\text { cutaneous } \\
(n=3,10.7 \%)\end{array}$ \\
\hline 4. & $\begin{array}{l}\text { Skin and soft tissue } \\
\text { infection } \\
(n=92,12.2 \%) \\
\text { - Superficial }(n=57) \\
\text { - Skin and soft tissue } \\
(n=14) \\
\text { - Secondary infection of } \\
\text { existing lesion }(n=11) \\
\text { - Skin abscess }(n=10)\end{array}$ & $\begin{array}{l}\text { Leishmaniasis, } \\
\text { cutaneous } \\
(n=6,9.5 \%)\end{array}$ & $\begin{array}{l}\text { Leishmaniasis, } \\
\text { cutaneous } \\
(n=8,10.3 \%)\end{array}$ & $\begin{array}{l}\text { Fungal infection } \\
\text { (superficial/cutaneous } \\
\text { mycosis) } \\
(n=9,10.7 \%)\end{array}$ & $\begin{array}{l}\text { Fungal infection } \\
\text { (superficial/cutaneous } \\
\text { mycosis) } \\
(n=5,7.3 \%)\end{array}$ & $\begin{array}{l}\text { Rash } \\
(n=3,10.7 \%) \\
\text { - Atopic dermatitis } \\
(n=2) \\
\text { - Urticaria/angioedema) } \\
(n=1)\end{array}$ \\
\hline 5. & $\begin{array}{l}\text { Pruritus, unknown origin } \\
(n=44,5.8 \%)\end{array}$ & $\begin{array}{l}\text { Skin and soft tissue } \\
\text { infection } \\
(n=6,9.5 \%) \\
\text { - Skin and soft tissue } \\
\text { infection }(n=4) \\
\text { - Superficial }(n=2)\end{array}$ & $\begin{array}{l}\text { Pruritus, unknown origin } \\
(n=6,7.7 \%)\end{array}$ & $\begin{array}{l}\text { Animal bite } \\
(n=7,8.3 \%) \\
\text { - Dog }(n=4) \\
\text { - Other }(n=3)\end{array}$ & $\begin{array}{l}\text { Pruritus, unknown origin } \\
(n=3,4.3 \%)\end{array}$ & $\begin{array}{l}\text { Myiasis } \\
(n=2,7.1 \%)\end{array}$ \\
\hline
\end{tabular}

\section{References}

1. Travel by Canadians to foreign countries, top 15 countries visited (2012). Ottawa: Statistics Canada, Tourism and the Centre for Education Statistics; 2011. Available: www.statcan.gc.ca/tables-tableaux/sum-som/101/cst01/arts37a-eng .htm (accessed 2015 Mar. 6).

2. National Tourism Indicators. Quarterly estimates, third quarter 2012. Ottawa: Statistics Canada; 2013. Available: www.statcan.gc.ca/nea-cen/list-liste/tourism -tourisme-eng.htm (accessed 2015 Mar. 19).

3. Delivering value for Canada's tourism businesses through innovation and efficiency. Canadian Tourism Commission annual report 2012. Vancouver: Canadian Tourism Commission; 2013. Available: http://en-corporate.canada.travel/sites/default/
files/pdf/Corporate_reports/ctc_2012_annual_report_low_res_e_-_may_2_2012 .pdf (accessed 2015 Mar. 6).

4. Hill DR. Health problems in a large cohort of Americans traveling to developing countries. 7 Travel Med 2000;7:259-66.

5. Lederman ER, Weld LH, Elyazar IR, et al.; GeoSentinel Surveillance Network. Dermatological conditions in the ill returned traveler: an analysis from the GeoSentinel Surveillance Network. Int 7 Infect Dis 2008;12:593-602.

6. Freedman DO, Weld LH, Kozarsky PE, et al.; GeoSentinel Surveillance Network. Spectrum of disease and relation to place of exposure among ill returned travelers. $N$ Engl 7 Med 2006;354:119-30.

7. Caumes E, Legros F, Duhot D, et al. Health problems in returning travelers consulting general practitioners. 7 Travel Med 2008;15:457-9. 
8. Boggild AK, Geduld J, Libman M, et al. Travel acquired infections and illnesses in Canadians: surveillance report from CanTravNet surveillance data, 2009-2011. Open Med 2014;8:e20-32.

9. Harvey K, Esposito DH, Han P, et al.; Centers for Disease Control and Prevention. Surveillance for travel-related disease-GeoSentinel Surveillance System, United States, 1997-2011. MMWR Surveill Summ 2013;62:1-23.

10. Leder K, Torresi J, Libman MD, et al; GeoSentinel Surveillance Network. GeoSentinel surveillance of illness in returned travelers, 2007-2011. Ann Intern Med 2013;158:456-68.

11. Monsel G, Caumes E. Recent developments in dermatological syndromes in returning travelers. Curr Opin Infect Dis 2008;21:495-9.

12. Caumes E, Carriere J, Guermonprez G, et al. Dermatoses associated with travel to tropical countries: a prospective study of the diagnosis and management of 269 patients presenting to a tropical disease unit. Clin Infect Dis 1995; 20:542-8.

13. Schofield S, Plourde P; Committee to Advise on Tropical Medicine and Travel. Statement on personal protective measures to prevent arthropod bites. Can Dis Wkly Rep 2012;38(ACS-3):1-18. Available: www.phac-aspc.gc.ca/ publicat/ccdr-rmtc/12vol38/acs-dcc-3/index-eng.php (accessed 2015 Mar. 6).

14. Leder K, Wilson ME, Freedman DO, et al. A comparative analysis of methodological approaches used for estimating risk in travel medicine. 7 Travel Med 2008;15:263-72.

Affiliations: Division of Dermatology, Department of Medicine (Stevens), University of Toronto, Toronto, Ont.; Travel and Migration Health Division (Geduld), Infectious Disease Prevention and Control Branch, Public Health Agency of Canada, Ottawa, Ont.; Division of Infectious Diseases, Department of Microbiology (Libman, Ward), and JD Maclean Centre for Tropical Diseases, McGill University Health Centre, Montréal, Que.; Tropical Medicine and International Health Clinic, Division of Infectious Diseases (McCarthy), Ottawa Hospital and the University of Ottawa, Ottawa, Ont.; Hôpital Saint-Luc du Centre Hospitalier de l'Université de Montréal (Vincelette), Montréal, Que.; Infectious Diseases (Ghesquiere), Vancouver Island Health Authority, Department of Medicine, University of British Columbia, Victoria, BC; Division of Infectious Diseases, Department of Medicine (Hajek), University of British Columbia, Vancouver, BC; Section of Pediatric Infectious Diseases, Departments of Pediatrics and Medicine (Kuhn), Alberta Children's Hospital and the University of Calgary, Calgary, Alta.; UAB Travelers Health Clinic with the Gorgas Center for Geographic Medicine, Division of Infectious Diseases (Freedman), University of Alabama at Birmingham, Birmingham, Alabama; SAR Laboratories (Kain), Sandra
Rotman Centre for Global Health, Toronto, Ont.; Tropical Disease Unit, Division of Infectious Diseases, Department of Medicine (Kain, Boggild), University Health Network and the University of Toronto, Toronto, Ont.; Public Health Ontario Laboratories (Boggild), Public Health Ontario, Toronto, Ont.

Contributors: Andrea Boggild and Michael Stevens conceived the analysis, contributed to study design and to the collection, analysis and interpretation of data, and were primarily responsible for writing and revising the manuscript. Jennifer Geduld contributed to study design, data interpretation and critical appraisal of the manuscript. Michael Libman, Brian Ward, Anne McCarthy, Jean Vincelette, Wayne Ghesquiere, Jan Hajek, David Freedman and Kevin Kain contributed to study design, data collection and interpretation, and appraisal and revision of the manuscript. Susan Kuhn contributed to study design, data interpretation, and appraisal and revision of the manuscript. All of the authors approved the version to be published and agreed to act as guarantors of the work.

Funding: Can'TravNet is the Public Health Agency of Canada's corresponding network for tropical and travel medicine that has been funded through the Travel and Migration Health Division of the Infectious Disease Prevention and Control Branch of the Public Health Agency of Canada (contract nos. 4500308220 and 4500305899 ). It is a subnetwork comprised of the Canadian sites of GeoSentinel, the Global Surveillance Network of the International Society of Travel Medicine, which is supported by Cooperative Agreement U50/CCU412347 from the Centers for Disease Control and Prevention. The funding source for CanTravNet contributed to study design and critical appraisal of the manuscript but did not have access to raw data. The funding source for GeoSentinel had no role in study design, data analysis, data interpretation or drafting of the manuscript. Kevin Kain was supported by a Canada Research Chair in molecular parasitology.

Competing interests: Andrea Boggild has received a grant from the Public Health Agency of Canada. Kevin Kain has received grants (MOP 13721 and 115160) from the Canadian Institutes of Health Research. Jennifer Geduld is employed by the Public Health Agency of Canada. No other competing interests were declared.

Supplemental information: For reviewer comments and the original submission of this manuscript, please see www.cmajopen.ca/content/3/1/ E119/suppl/DC1 